\title{
Gaining legitimacy through CSR: an analysis of Turkey's 30 largest corporations
}

\section{Emel Ozdora-Aksak ${ }^{1}$ and Sirin Atakan-Duman ${ }^{2}$}

\author{
1. Faculty of Fine Arts, Design and Architecture, Department of Communication and Design, Bilkent University, Ankara, \\ Turkey \\ 2. Faculty of Economics and Administrative Sciences, Department of Business Administration, Turgut Ozal University, \\ Ankara, Turkey
}

\begin{abstract}
Grounded in institutional theory, this study provides an overview of the corporate social responsibility (CSR) initiatives of Turkey's 30 largest corporations through a thematic content analysis. The study focuses on the G-20 member Turkey and investigates the influence of isomorphism mechanisms on the adoption of CSR initiatives in a developing country context. The aim of this study is to integrate Carroll's CSR dimensions, the type of CSR engagement and coercive, mimetic and normative isomorphism mechanisms proposed by institutional theory. Through this integration the study makes a unique contribution to the literature by providing a different perspective. Findings reveal industry characteristics do not influence the selection of CSR initiatives. While business-to-business companies focus on CSR activities linked to their core business functions, business-to-consumer companies focus on CSR initiatives that are more discretionary, varied and philanthropic. In addition, findings show that multinational corporations implement CSR initiatives at the global level rather than focusing on local needs.
\end{abstract}

\section{Introduction}

This study provides an overview of the corporate social responsibility (CSR) initiatives by the 30 largest companies in Turkey to understand how they utilize CSR to construct and communicate their organizational identities online. This research uses the theoretical framework provided by institutional theory and argues that corporations need to conform to the values and norms of their institutional environments (Powell \& DiMaggio 1981), construct a moral identity and communicate this identity to stakeholders to survive and succeed.

This study also attempts to contribute to the international literature on CSR by enhancing the understanding of the interrelationship between organizational communication, organizational identity, and CSR by providing an analysis from Turkey. Kurokawa \&
Macer (2008) have underlined the importance of studying country-specific conditions to understand the CSR scene in a country. Turkey's governmental policies support economic development rather than focusing on long-term social and environmental impact (Marsden 2000; Özen \& Özen 2004), and there is a lack of strict regulations and social sensitivity about environmental issues (Özen \& Küskü 2009). As CSR norms have not been clearly defined, there seems to be an uncertainty in ethical norms in the business environment and this lack of national level CSR norms and regulations leads to the adoption and mimicking of global CSR trends. Therefore, companies adopt CSR initiatives that are not addressing local needs and expectations such as arts and culture, although education and health activities may have priority in a given context. Global CSR trends can be considered as the types of CSR initiatives that are commonly 


\section{Business Ethics: A European Review \\ Volume 25 Number 3 July 2016}

implemented by multinational companies which do not address local needs and/or priorities but tend to be driven by global and popular trends such as investing in the environment or the arts.

Uncertainty is prevalent in Turkey's legal system as the state does not guarantee the implementation of laws in the same manner or to the same degree in all cases and the state remains the major actor leading change in the country, intervening to a large extent in the national economy (Atakan-Duman 2010). There is a high dependency on credit in the financial system, uncertainties and gaps in the legal system, and lastly paternalistic characteristics influence the political and economic instability in the country (Atakan-Duman, 2010). Therefore, companies and institutions need to find ways to avoid the uncertainty created by the state (Gökşen \& Üsdiken 2001; Buğra 2005).

Academic research on CSR in Turkey has increased significantly in recent years (Özen \& Küskü 2009; Türker 2009; Ertuna \& Ertuna 2010; Ertuna \& Tükel 2010; Zora 2011; Bıçakçı and Hürmeriç 2013; Ozdora-Aksak \& Atakan-Duman 2014). This study's goal is to examine CSR and organizational identity related information presented on the corporate websites of Turkey's 30 largest companies, understand CSR variation according to industry, and lastly reveal differences between CSR initiatives of business-tobusiness (B2B) vs. business-to-consumer (B2C) companies as well as between multinationals vs. locals. Furthermore, this paper proposes to contribute to existing literature by examining CSR practices outside the US or Europe and develop a deeper understanding of the CSR scene in Turkey. The study investigates the influence of isomorphism mechanisms on CSR initiatives in a developing country context with a growing economy. As Turkey is weakly represented in the CSR literature, the authors believe that the study will shed light on CSR and isomorphism mechanisms from a different context.

The theoretical background on communication and institutional theory is introduced and discussed in the next section. The methodology section outlines the sample selection and data collection process and the thematic content analysis utilized in the study. The results and discussion section presents the findings of the website analysis and identifies different CSR patterns according to different industries and types of organizations and puts forward proposi- tions related to CSR and isomorphism mechanisms. The conclusions section elaborates on the results and implications of the study for Turkey as well as for developing countries, lists the study's limitations, and proposes new areas for future research.

\section{Literature review}

Grounded in institutional theory, this study intends to uncover the influence of industry classification on the CSR activities of Turkey's largest companies to examine the influence of business type (B2B or B2C) and geographic concentration (MNC or local companies) on the isomorphic adoption and diffusion of CSR activities. Furthermore, the relationship between CSR, isomorphism mechanisms, and organizational identity is examined in a developing country context. This section outlines the theoretical background of the study, highlighting literatures on organizational identity and CSR, followed by the conceptual framework and research questions.

\section{Organizational identity and institutional theory perspective}

As Olins (1989) argued, all organizational activities, products/services, and communication efforts play an important role in organizational identity construction. Aust (2004: 523) has defined organizational identity as 'an organization's distinctive character discernible by those communicated values manifest in its externally transmitted messages'. Organizational identity provides meaning for organizational members by highlighting values, beliefs and patterns of behavior (Albert \& Whetten 1985). Various stakeholders infer meaning from the constructed (Ravasi \& Schultz 2006; Zellweger et al. 2013) and communicated organizational identity as organizations sustain their identities through communication (van Riel \& Balmer 1997).

Institutional theory helps explain the complex nature of institutional environments and reciprocal pressures between an organization and its context (Scott 2008). This reciprocal influence of the organization and its context also influence CSR initiatives. It has been proposed that institutional environments strongly influence the national CSR scene (Campbell 2007), as well as organizational actions (Wooten \& 


\section{Business Ethics: A European Review}

Volume 25 Number 3 July 2016

Hoffman 2008). As argued by DiMaggio \& Powell (1983), once a few players or a major one in an industry engages in a certain action, competitors or even players in other industries tend to implement actions to adapt to the new institutional context through various isomorphism mechanisms.

Organizations try to adapt to their environments and act in an isomorphic manner to resemble each other by imitating legitimate practices (DiMaggio \& Powell 1983; Dacin 1997; Long \& Driscoll 2008). DiMaggio \& Powell (1983) have identified three mechanisms of isomorphism: coercive, mimetic and normative. Coercive isomorphism results from formal pressures such as legal requirements or informal pressures like cultural expectations exerted by the society (DiMaggio \& Powell 1983). The second mechanism of institutional isomorphic change, mimetic processes, are triggered by high levels of environmental uncertainty where organizations try to mimic successful or legitimate models within their organizational fields (DiMaggio \& Powell 1983). Lastly, normative isomorphism is a result of professionalization that may stem from formal education or a filtering mechanism such as hiring individuals from the same industry or professional networks (DiMaggio \& Powell 1983). Greenwood et al. (2002) and Suchman (1995) suggested that normative isomorphism results from both norms of the profession and the society. Organizations try to imitate best practices to avoid being perceived as illegitimate if they fail to meet social needs or societal expectations (Sethi 1975; Campbell 2007). This seems to be the rationale behind most organizational CSR initiatives and their communication.

\section{CSR as a response to institutional pressures}

Organizations are under increasing pressure to apply environmental, social, ethical, and responsible standards to their business activities and define their role in society (Lichtenstein et al. 2004; Lindgreen et al. 2009; Maon et al. 2010). This pressure has led to an increase in CSR focus in business practices as well as academic literature (Kotler \& Lee 2005; McWilliams et al. 2006; Lamberti \& Noci 2012). Kotler \& Lee (2005: 3) defined CSR as the 'commitment to improve community well-being through voluntary business practices and contributions of corporate resources'. Another definition by McWil- liams \& Siegel (2001) underlined the importance of CSR for advancing social good by doing more than what is specified by legal requirements and going beyond the interests of the organization. Carroll's (1979) broad definition of CSR includes economic responsibilities, which suggest being profitable financially; legal responsibilities such as obeying the law; ethical responsibilities that reflect companies' respect for societal values such as gender or inclusiveness; and discretionary responsibilities which show the company in a good light as a good corporate citizen that engages in philanthropic activities. CSR practices and corporate social disclosures are becoming increasingly influential in determining how stakeholders view organizations.

Based on social identity theory, Bhattacharya \& Sen (2003) argued that consumer-company identification is positively influenced by CSR. In fact, companies with a strong CSR agenda tend to nurture positive customer attitudes, are viewed more favorably, and are rewarded financially (Hsu 2012). Employees are a critical stakeholder group for the development and implementation of successful CSR initiatives. Story \& Neves (2015: 118) investigated the motives employees attribute to CSR initiatives and how they impact employee performance. The authors revealed that that employees attribute both intrinsic and extrinsic motives to CSR, acknowledging CSR initiatives "that "create good" to stakeholders without any expectations to the organization, but also believe that organizations invest in CSR activities strategically to create value'. In their paper where they acknowledge the importance of employees to CSR, Jamali et al. (2015) argued that human resource management (HRM) could provide an interesting and dynamic support to CSR strategy design and implementation. They proposed that HRM could contribute to CSR by 'building on CSR's implementation challenges and integration with business operations, as well as mainstream mission and strategic objectives' (2015: 131), such as ensuring that 'CSR implementation is well supported, resonates with employees, and is integrated with internal working systems and policies' (2015: 134).

\section{Global versus local CSR}

As argued by Kurokawa \& Macer (2008), to better understand the CSR scene in a country, it is 


\section{Business Ethics: A European Review}

Volume 25 Number 3 July 2016

important to reveal the impact of country conditions on CSR and determine whether CSR is used by companies as a response to national priorities such as health or education, or a need to engage in a globally popular CSR domain such as environmental initiatives. Some scholars have argued that global pressures and trends have a strong influence on CSR initiatives around the world. In their study that focuses on the CSR scene in Lebanon, Jamali \& Neville (2011) suggested that international or more Western styles of CSR are diffusing into the developing world, while Matten \& Moon (2008) underlined the significance of global institutional pressures in the spread of institutionalized and explicit CSR practices.

Conversely, some authors have stressed the influence of context on social responsibility. Organizational expectations in terms of economic, legal, ethical, and discretionary responsibilities tend to be influenced by the culture of a country (Burton et al. 2000; Küskü \& Zarkada-Fraser 2004; Chapple \& Moon 2005; Matten \& Moon 2008). In their paper which focuses on CSR consulting in Greece, Skouloudis \& Evangelinos (2014: 258) revealed how CSR initiatives tend to be "primarily induced by supranational and international policy schemes as well as foreign competitors' with a lack of strategic management approach to CSR and strong institutional coordination.

Aggerholm \& Trapp (2014) examined CEO introductory letters in the companies' annual sustainability reports from 2009 to evaluate the CSR initiatives of four energy companies active in Nordic countries. Their findings revealed that CSR activities are rooted in both second- and third-generation approaches to CSR where the goal is not only to benefit 'the organizations' closest stakeholders, such as shareholders and consumers, but also society in general' (Aggerholm \&Trapp 2014: 243). In their discussion, the authors proposed that CSR initiatives should be chosen according to their contribution to the organization as well as its characteristics such as 'company size, corporate values, or degree of interaction with the local community' (Aggerholm \&Trapp 2014: 245), rather than based on a global, third-generation approach.

Küskü \& Zarkada-Fraser (2004) investigated the CSR activities of Turkish and Australian companies and proposed that even though Turkish companies seem to be less focused on environmental and antidiscrimination laws in comparison to Australian companies, they are more inclined to engage in voluntary CSR initiatives to support local communities as they seek legitimacy through CSR in a business environment with loose regulations. Visser (2008) asserted that the CSR field in developing countries is in fact more extensive than assumed and not as politically rooted, but also closely connected to cultural and religious values of the country, targets local communities (Visser 2008; Jamali et al. 2009), and leads to the implementation of programs not effectively addressed by governments (Frynas 2005; Amaeshi et al. 2006).

\section{Conceptual framework of the study}

In light of the literature presented above, the conceptual framework of the study makes an attempt to integrate the CSR responsibilities defined by Carroll (1979), the type of CSR engagement, and coercive, mimetic and normative isomorphism mechanisms (DiMaggio \& Powell 1983). The conceptual model presented in Figure 1 categorizes CSR activities according to the three different CSR engagement types: core business focused CSR initiatives, discretionary CSR initiatives, and a third category which includes both core business focused and discretionary CSR initiatives.

The three CSR engagement types were identified conceptually by the authors based on the degree of closeness of the CSR initiative to the core business function and the targeted stakeholder group (immediate stakeholders such as customers, employees, stockholders, etc. vs. the larger community). Core business focused CSR initiatives create a competitive advantage as they are more closely linked to economic and legal responsibilities (Carroll 1979), they are more strategic as they involve the usage of company products and services, and they target immediate stakeholders (e.g. Türk Telekom's Technology Laboratories which provides training to prospective employees that contribute to the company through high quality employee potential). The authors suggest that core business focused CSR initiatives, which address economic and legal responsibilities through coercive isomorphism, are implemented to avoid 


\section{Business Ethics: A European Review}

Volume 25 Number 3 July 2016

Figure 1: The relationship between business area/industry focus and variety of CSR initiatives

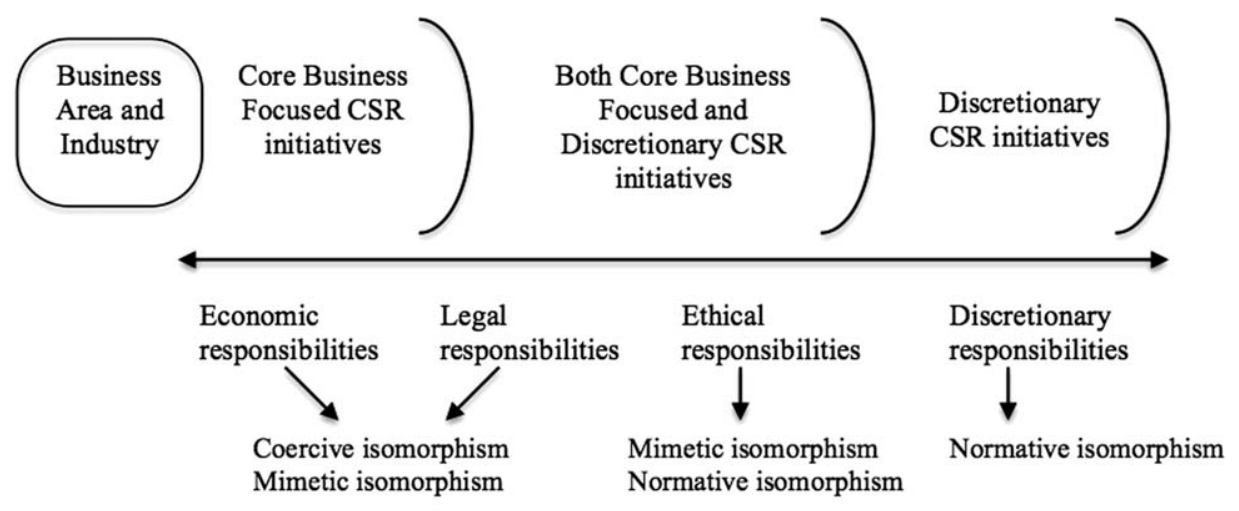

Source: Authors

punishment due to regulations such as legislation, policies, media, and other powerful industry actors (Sharma 2000; Özen \& Küskü 2009).

Conversely, discretionary CSR initiatives are more philanthropic, often bear no direct connection to a company's core business function, and target the larger community instead of immediate stakeholders. They include activities such as sponsoring sports events, archeological excavations, or constructing schools, as they are based more on ethical and discretionary responsibilities (Carroll 1979). Organizations engage in these initiatives in response to normative institutional pressures to conform to societal norms and values (Suchman 1995). Through normative isomorphism, organizations adopt broader societal norms (Swanson 1999), act with philanthropic concerns and support societal wellbeing. Therefore, organizations move further away from a merely core business focus towards a more philanthropic agenda (e.g. Hedef Alliance pharmaceutical warehousing company engages in art and culture initiatives such as sponsoring archeological excavations and art exhibitions).

The final category, both core business focused and discretionary CSR initiatives was conceptualized by the authors to identify CSR initiatives that fall under both CSR types. For example Migros' CSR initiatives related to the natural environment can include initiatives that reflect its core business function (e.g. Migros' biodegradable plastic shopping bag initiative) and also have discretionary concerns (e.g. Migros' reforestation initiatives). CSR initiatives that fall under this category address both economic, legal but also ethical and discretionary responsibilities, and target all stakeholder groups as organizations engage in these activities to avoid punishment as well as to obtain social approval (Özen \& Küskü 2009). These types of CSR initiatives address compatibility with norms and regulations, mimicking industry standards and institutional ideals (Suchman 1995). It can be argued that organizations that engage in these varied CSR initiatives are driven by both strategic and ethical concerns (e.g. motor vehicles manufacturing company Ford Otosan's education initiatives that provide employee training programs close to its core business function through its Vocational Education for Professional Employees Project, and primary education support by building libraries and contributing to community development).

The CSR engagement types presented in the conceptual framework overlap with Carroll's (1979) categories of economic, legal, ethical, and discretionary responsibilities. CSR dimensions identified by Carroll were conceptualized as a continuum in this study rather than separate independent dimensions. The rationale behind this conceptualization was the blurred distinction between dimensions and the difficulty of identifying the main responsibility motive that leads to the CSR activity. An activity may dominantly rely on ethical concerns but could be discretionary to some extent. Moving further from economic responsibilities toward discretionary responsibilities, CSR initiatives move from activities that have a core business focus toward more ethical and discretionary CSR initiatives. 


\section{Business Ethics: A European Review \\ Volume 25 Number 3 July 2016}

Furthermore, when there is uncertainty in the institutional environment, companies need to conform to widely accepted industry practices through mimetic isomorphism. Therefore, CSR activities with economic and legal concerns are adopted and diffused through coercive and mimetic isomorphism mechanisms where the organization either tries to avoid punishment or uncertainty respectively. In addition, organizations may also engage in discretionary and philanthropic initiatives, as they want to contribute to social welfare through normative isomorphism. The conceptual framework suggests that CSR initiatives may diffuse through mimetic isomorphism when there is high uncertainty in the institutional environment, which may result in the mimicking of global CSR trends.

The first research question this study addresses is how industry classification influences the adoption of different CSR initiatives through which isomorphism mechanisms, and to identify whether any industry-specific orientations exist.

RQ1: What is the influence of industry classification on the CSR activities of Turkey's largest companies from an institutional theory perspective?

Secondly, this research also attempts to reveal differences between CSR approaches of B2B and B2C businesses in Turkey. B2B companies have relationships between two companies as supplier and customer (Kolis \& Jirinova 2013) and include a high number of complex transactions (Saini et al. 2010). Gummesson (2008) underlined the difference between $\mathrm{B} 2 \mathrm{~B}$ and $\mathrm{B} 2 \mathrm{C}$ companies as greater independence between buyers and sellers in B2B markets. Furthermore, González Benito \& González Benito (2006) asserted that B2B companies have less pressure to engage in environmental social responsibility in comparison to $\mathrm{B} 2 \mathrm{C}$ companies leading to more reactive CSR practices. While $\mathrm{B} 2 \mathrm{~B}$ businesses are assumed to not engage heavily in CSR, this does not apply to B2C businesses. B2C companies have higher visibility, are influenced more by consumer pressures and media scrutiny, and need to be more involved in social responsibility (Bowen 2000; Hall 2000).

Conversely, others have argued that B2B businesses do not have the luxury to ignore CSR. Hoej- mose et al. (2012) suggested that B2B companies are under pressure from marketing and supply chain practitioners to enhance their environmental practices. This not only results from external pressures but from the belief that it can help improve performance and competitiveness (Sharma et al. 2010), as trust and personal relationships are critical for the success of B2B companies (Andersen \& Kumar 2006; Arnott 2007). Therefore the second research question aims to answer the following question:

RQ2: What is the influence of business type (B2B or B2C) on the isomorphic adoption and diffusion of CSR activities in Turkey?

The final research question is related to how isomorphic adoption and diffusion of CSR activities differ in MNCs versus local companies in Turkey. Jamali (2010) has aimed to reveal the factors influencing the CSR involvement of MNC subsidiaries in developing countries as well as understand the impact of globalization versus localization. The author argued that although global strategies tend to be more proactive, efficient, and integrated, they may face challenges at the local level in regards to ownership and legitimacy, while localized or decentralized strategies may risk being perceived as fragmented or ad hoc despite being locally created (Jamali 2010). Based on this argument, the study aims to understand the differences between the adoptions of CSR initiatives by local companies versus MNCs in Turkey to reveal patterns in their CSR involvement:

RQ3: What is the influence of geographic concentration (MNC or local companies) on the isomorphic adoption and diffusion of CSR activities in Turkey?

\section{Methodology}

The authors focused on Turkey's largest companies as previous studies have shown that larger companies have stronger CSR engagements (Luo \& Bhattacharya 2006; Campbell 2007; Caroll 2010). To understand how Turkey's largest companies utilize CSR, the focus of companies' CSR initiatives ranging between core business focused CSR initiatives, 
Table 1: Turkey's 30 largest companies by industry and revenue

\begin{tabular}{|c|c|c|c|c|c|}
\hline Rank & Company name & $\begin{array}{l}\text { Company } \\
\text { type }\end{array}$ & ISIC & Industry & $\begin{array}{l}\text { Revenue } \\
\text { (Billion TL) }\end{array}$ \\
\hline 1 & Tüpraş & Local & D-23 & Manufacturing/Energy & 47.00 \\
\hline 2 & Petrol Ofisi & Local & G-50 & Retail Fuel Sales & 20.20 \\
\hline 3 & Turkish Airlines & Local & $1-62$ & Air Transport & 14.90 \\
\hline 4 & Opet & Local & G-50 & Retail Fuel Sales & 14.71 \\
\hline 5 & Türk Telekom & Local & $\mathrm{I}-64$ & Telecommunications & 12.70 \\
\hline 6 & Phillip Morris/Sabancı & MNC & $D-16$ & Tobacco & 12.69 \\
\hline 7 & Shell/Tucas Petrol & MNC & G-50 & Retail Fuel Sales & 12.24 \\
\hline 8 & Arçelik & Local & C-27 & Domestic Appliances & 10.55 \\
\hline 9 & Turkcell & Local & $\mathrm{I}-64$ & Telecommunications & 10.50 \\
\hline 10 & Enka Construction & Local & $\mathrm{F}-45$ & Construction & 10.29 \\
\hline 11 & BIM & Local & G-47 & Retail Trade (Grocery) & 9.90 \\
\hline 12 & Ford Otosan & MNC & C-29 & Manufacture of Motor Vehicles & 9.70 \\
\hline 13 & Erdemir & Local & C-24 & Manufacture of Basic Metals & 9.50 \\
\hline 14 & Oyak-Renault & MNC & C-29 & Manufacture of Motor Vehicles & 7.53 \\
\hline 15 & Vestel Electronic & Local & C-26 & Manufacture of Consumer Electronics & 7.51 \\
\hline 16 & TOFAS & Local & C-29 & Manufacture of Motor Vehicles & 6.70 \\
\hline 17 & Hedef Alliance Group & MNC & $\mathrm{H}-52$ & Warehousing and Storage & 6.50 \\
\hline 18 & Migros & Local & G-47 & Retail Trade (Grocery) & 6.47 \\
\hline 19 & Anadolu Efes Biracılık & Local & C-11 & Manufacture of Beverages & 6.41 \\
\hline 20 & ICDAS Celik Enerji & Local & C-24 & Manufacture of Basic Metals & 6.24 \\
\hline 21 & JTI Tobacco & MNC & C-12 & Tobacco & 5.60 \\
\hline 22 & AYGAZ & Local & D-35 & Manufacture of Gas & 5.58 \\
\hline 23 & Vodafone & MNC & $\mathrm{I}-64$ & Telecommunications & 5.50 \\
\hline 24 & Sisecam & Local & C-23 & Manufacture of Glass & 5.30 \\
\hline 25 & Mercedes-Benz Turk & MNC & G-45 & Wholesale and Retail of Motor Vehicles & 5.20 \\
\hline 26 & Dogus Automotive & Local & G-45 & Wholesale and Retail of Motor Vehicles & 5.10 \\
\hline 27 & Selcuk Pharmacy Warehouse & Local & $\mathrm{H}-52$ & Warehousing and Storage & 4.90 \\
\hline 28 & Enerji SA & Local & D-35 & Electricity Supply & 4.57 \\
\hline 29 & Petkim & Local & C-20 & Manufacture of Chemicals & 4.34 \\
\hline 30 & Coca-Cola & MNC & C-11 & Manufacture of Beverages & 4.10 \\
\hline
\end{tabular}

both core business focused and discretionary CSR initiatives, and discretionary CSR activities were identified conceptually by the researchers. In addition, the concentration of CSR activities according to industry, business type, and geographic concentration were further investigated.

\section{Sample selection and data collection}

The companies analyzed in this study were selected from Capital Business Journal's 2013 top-500 list for Turkey and categorized according to the United Nations' two-digit International Standard Industrial
Classification: manufacturinglenergy, air transport, tobacco, domestic appliances, construction, telecommunications, retail trade, warehousing, and retail fuel sales. Table 1 lists the company distribution according to rank, industry, and revenue.

Table 1 reveals that while nine of the largest companies are subsidiaries of multinationals in Turkey, there are 21 local corporations in the top 30 list. In addition, the most popular industry is manufacturing with 12 companies. CSR data was collected from corporate websites, which are increasingly being used in academic research (Ettredge et al. 2001; Maignan \& Ralston 2002; Bonsón et al. 2008; 


\section{Business Ethics: A European Review}

Volume 25 Number 3 July 2016

Wanderley et al. 2008; Moreno \& Capriotti 2009; Waters et al. 2010; Gallego-Alvarez et al. 2011; Verboven 2011; Du \& Vieira 2012; Bonsón \& Ratkai 2013; Ozdora-Aksak \& Atakan-Duman 2015). Corporate websites are an important tool for companies to engage with their stakeholders (Verboven 2011) and they are commonly used for CSR reporting (Maignan \& Ralston 2002; Moreno \& Capriotti 2009; Lee et al. 2009; Du et al. 2010). The CSRrelated data was collected from the About Us, History, Mission and Vision, and Corporate Social Responsibility sections of each corporate website.

\section{Coding and data analysis}

The CSR categorization used to code the CSR activities of Turkey's largest 30 companies were developed by the two researchers who separately analyzed the content through pre-readings and then detailed readings to determine (1) the CSR types according to the type of initiatives such as environment, education, culture and arts, and so forth, and (2) the CSR engagement types of each company in terms of closeness of business focus or inclination to philanthropic and discretionary concerns.

Coding started with grouping the CSR initiatives of each company according to type of initiatives such as environment, education, culture and arts, etc. These CSR types were firstly inspired by David et al.'s (2005) study on CSR. In their study, David et al. (2005: 303) grouped CSR activities according to type of practice such as 'contributes resources to the arts and cultural programs in the community', 'contributes resources to raise social awareness of issues such as hunger and domestic violence', 'supports children and family issues', 'treats employees fairly', 'acts responsibly toward the environment', 'supports public health programs', and so forth. In addition, the CSR coding system used by OzdoraAksak \& Atakan-Duman (2015) was also utilized to categorize CSR initiatives. Furthermore, the companies analyzed had also grouped their CSR initiatives under various categorization systems on their websites and these categorizations were also integrated into the data coding process. After a few companies were analyzed and coded, a detailed coding scheme started to develop. In line with Long \& Driscoll (2008), the researchers allowed alternative codes to emerge from the text, and mutually discussed and added new categories as they were needed or as they appeared on corporate websites.

This detailed coding and analysis process resulted in seven major CSR types; culture and arts (archeological excavations, sponsorship to art exhibitions, concerts, and festivals), education (building schools and school facilities, book donations, scholarships), environment (energy consumption, recycling of waste, decreasing air and water pollution, foresting), occupational health and safety (workplace safety, increasing awareness through education on occupational health), professional development (building technical and professional schools, employee education/training programs, certificate programs), public health and sports (increasing awareness on public health, sponsorship of sports clubs), social sensitivity (respect for human rights, social aids), and disadvantaged groups (disabled and female participation in business life).

The second step in the coding process involved the identification of the CSR engagement type of each company according to closeness to business focus or inclination to philanthropic and discretionary concerns. The seven major CSR types were grouped under three main classifications as being core business focused CSR initiatives, discretionary CSR initiatives, and both core business focused and discretionary CSR initiatives. Table 2 presents the coding category, description, and rules used to identify the CSR engagement type of the companies.

As presented in Table 2, the framework identifies three types of CSR focus and scope; core business focused CSR initiatives, discretionary CSR initiatives, and lastly both core business focused and discretionary CSR initiatives. Core business focused CSR initiatives tend to create a competitive advantage for companies as they are more in line with their economic and legal responsibilities (Carroll 1979), more strategic as they involve the usage of company products and services, and target immediate stakeholders. On the other hand, discretionary CSR initiatives are more philanthropic in nature and have no direct connection to a company's core business focus, and target the larger community through activities such as sponsoring sports events, archeological excavations, or constructing schools, as they are more closely linked to ethical and philanthropic 


\section{Business Ethics: A European Review}

Volume 25 Number 3 July 2016

\section{Table 2: Coding scheme for identifying the CSR engagement type of the companies}

\section{Coding category \\ Core business focused \\ CSR initiatives}

Discretionary CSR

initiatives

Both core business

focused and discretionary

CSR initiatives

\section{Category description}

- Reflects core business function (e.g. Colgate's oral health initiative targeting consumers involves the use of product and services and aims to increase consumption of tooth brush and tooth paste)

- Addresses economic responsibilities and legal regulations

- More strategic

- Targets immediate stakeholder (customers, employees, stockholders, partners, suppliers, distributors)

- No connection with core business function (e.g. arts exhibitions and music festivals organized by banks)

- Ethical, discretionary and philanthropic

- Less strategic

- Targets larger community instead of immediate stakeholders

- CSR activity (e.g. environment) that falls under both categories as an activity can include initiatives that reflect core business function (e.g. Migros' degradable plastic shopping bag initiative) and also discretionary with an external focus (e.g. Migros' reforestation initiatives)

- Addresses economic, legal but also ethical and discretionary responsibilities

- Targets all stakeholder groups

\section{Coding rule}

- Is the initiative industry related/ specific?

- Does the initiative involve the use of company products or services?

-Who is the target of the initiative?

- Does the initiative have an extensive impact, which is not industry specific?

-Who is the target of the initiative?

- Does the initiative have an extensive impact and also is the initiative industry related/specific?

- Who is the target of the initiative?

Source: Authors.

responsibilities (Carroll 1979). The final category, both core business focused and discretionary CSR initiatives, address both economic and legal but also ethical and discretionary responsibilities targeting all stakeholder groups.

To determine how companies differ from each other, the CSR types and companies' CSR engagement types were compared. In addition, the concentration of CSR activities according to industry was calculated to reveal industry-specific CSR trends. Industry concentration of CSR initiatives was calculated by dividing the industry total of CSR initiatives related to core business focus by the industry total of
CSR initiatives by the companies in the same industry. Concentration of CSR activities according to industry were analyzed to determine whether there were any variations between different industries' CSR initiatives (see Appendix). This process is further elaborated in the results section and Table 3 presents the industry CSR concentration values.

To ensure reliability of the analysis, the authors first separately read the CSR data and came up with CSR coding categories based on the process described above. Later, the authors went over the coding categories together to agree on and finalize the CSR types that were used in the study. 
Table 3: CSR engagement types of Turkey's largest 30 companies

Industry
Tobacco
$\begin{gathered}\text { Manufacture/Retail of } \\ \text { motor vehicles }\end{gathered}$

Energy/Oil

Manufacture of basic metals

Air transport

Manufacture of beverages

Manufacture of glass

Telecommunications

Retail trade (Grocery)

Warehousing and storage/pharmaceuticals

Consumer electronics

Construction

\section{Company name}

JTI Tobacco

Phillip Morris/Sabancı

Dogus Automotive

Ford Otosan

Mercedes-Benz Turk

Oyak-Renault

TOFAS

AYGAZ

Enerji SA

Opet

Petkim

Petrol Ofisi

Shell/Tucas Petrol

Tüpraş

Erdemi

ICDAS Celik Enerji

Turkish Airlines

Anadolu Efes Biracılık

Coca-Cola

Sisecam

Telekom

Turkcell

Vodafone

BIM

Migros

Hedef Alliance Group

Selcuk Pharmacy Warehouse

Arçelik

Vestel Electronic

Enka Construction
CSR related to core business functions/Total CSR

1

0.74

0.56

0.50

0.50

0.47

0.44

0.33

0.29

0.14

0

0
Focus of CSR activities

Core business focused CSR initiatives

Both core business focused and discretionary CSR initiatives

Discretionary CSR initiatives

Source: Authors.

Afterwards, the authors coded all the CSR data individually followed by a discussion of codes and mutually agreed on the coding of all CSR types. As the codes and CSR types were easily identified, there was not much discrepancy between the two researchers. The type of CSR engagement was also further coded by the authors according to the coding scheme for identifying the CSR engagement type of companies through the same coding procedure described above. The authors had a few incidents where the CSR engagement type was not immediately agreed upon; however, the authors discussed those incidents until coding discrepancies were resolved though mutual agreement. The coding process was finalized after all CSR activities and types of CSR engagements were coded and categorized.

\section{Results and discussion}

Study findings revealed that the CSR scene in Turkey is quite varied as initiatives implemented by Turkish companies address all the different CSR dimensions suggested by Carroll (1979). One of the most 


\section{Business Ethics: A European Review}

Volume 25 Number 3 July 2016

significant contributions of this study is to establish a linkage between Carroll's CSR dimensions and isomorphism mechanisms. The findings related to the first research question, which focuses on analyzing CSR activities according to industry, are detailed in Table 3 .

As presented in Table 3, to reveal the industry CSR focus on core business function, the industry total was calculated for CSR initiatives related to core business focus by adding them up. Then the industry total of CSR initiatives related to core business focus were divided by the industry total of all CSR initiatives within the same industry category. Thus the ratios presented in Table 3, which reveal the CSR focus according to industry, were generated. Scores of 1.00-0.60 represent industries that engage in core business focused CSR initiatives, 0.590.40 represent industries that engage in both core business focused and discretionary CSR initiatives, $0.39-0$ represent industries that engage more in discretionary CSR initiatives.

The weight of each industry's CSR focus was determined by identifying its emphasis on activities related to its core business focus relative to the total of its CSR initiatives (Table 3). As an example, in retail trade of grocery industry, only BIM and Migros were investigated. Migros has seven CSR initiatives and BIM has none. As a result the industry total is seven for retail trade of grocery industry. Two of Migros' CSR initiatives are core business focused. Therefore the weight of core business focused CSR initiatives of Migros were coded as 2/7 (CSR activities related to core business focus divided by the total number of CSR activities within the industry), which equals 0.29 and reveals that Migros' CSR activities are more discretionary than business focused. Each company's weight in each industry was calculated and the total industry scores were obtained by adding up company scores operating within the same industry. All industry-wide coding processes in this article were conducted similarly.

Study results revealed that a group of companies within the same industry may engage only in core business focused or discretionary CSR initiatives. The findings of the study put forward that the manufacture/retail of motor vehicles industry and tobacco industry implement CSR activities related to their core business focus as they prioritize economic and legal concerns, which lead to avoiding economic and legal punishments. Consequently, companies operating in these industries may adopt CSR initiatives through coercive isomorphism. As suggested by Castelló \& Lozano (2011), such initiatives emphasize organizational interests and tend to be relatively more strategic as they target short-term economic benefits for the organization.

Findings reveal that companies operating in energy/ oil industry, manufacture of beverages, glass, basic metals, and air transportation implement CSR activities related to their core business focus and discretionary CSR initiatives simultaneously as they have economic, legal, and ethical concerns. As a result, companies operating in these industries adopt CSR initiatives both to avoid economic and legal punishments and to conform to social norms; therefore, both coercive and normative isomorphism mechanisms may be instrumental. Finally, companies operating in retail trade, warehousing and storage of pharmaceuticals, telecommunication, consumer electronics, and construction industries implement CSR activities that are discretionary and they prioritize fulfilling their responsibilities towards the community. Therefore, companies operating in these industries may adopt CSR initiatives through normative isomorphism.

As presented in the theoretical framework, this study aims to establish a linkage between the four CSR dimensions proposed by Carroll (1979) and institutional theory's three isomorphism mechanisms. According to this linkage, coercive isomorphism is instrumental when companies prioritize economic and legal responsibilities to avoid punishment (Sharma 2000; Özen \& Küskü 2009). Companies also engage in discretionary CSR initiatives when they want to contribute to their communities through normative isomorphism. Conversely, if there is uncertainty in their institutional environments, companies conform to common industry practices through mimetic isomorphism.

The first research question this study aimed to understand was whether industry classification influenced the adoption of different CSR initiatives through which isomorphism mechanisms, and to identify whether any industry-specific orientations existed. However, an overall industry analysis indicates that industry type does not have an influence on the selection of CSR initiatives. An industry 


\section{Business Ethics: A European Review}

Volume 25 Number 3 July 2016

concentration of CSR initiatives could not be identified. This may result from the lack of CSR-related regulations in the business environment in Turkey. Although influenced by global trends as a developing country and a growing economy, the Turkish business environment preserved its local characteristics. Domestic ownership, small size, and nascent formal structures (Erçek 2006) in the Turkish business environment have limited the full adaptation of these global and modern values (Berkman \& Özen 2008). In addition, the governmental policies of Turkey focus on supporting economic development rather than addressing social concerns (Marsden 2000; Özen \& Özen 2004), and there is a lack of strict regulations (Özen \& Küskü 2009). These poorly defined CSR norms and regulations create uncertainty in the institutional environment, which causes mimicking of global CSR trends.

The findings related to the second research question which explores the differences between CSR initiatives of B2B and B2C companies yielded three inferences. Firstly, results revealed that companies engaged in B2B activities (i.e. selling products to or servicing businesses) tend to engage in CSR initiatives that are related to their core business functions. For example EnerjiSA, Turkey's largest electricity supplier, only engages in CSR activities related to the environment and occupational health and safety, which are directly related to its core business function. As argued by Hoejmose et al. (2012), B2B companies feel the pressure from the market and supply chains to enhance their CSR agendas. Consequently, B2B companies implement CSR activities that address their economic and legal responsibilities that are closely related to their core business focus. Therefore, the following proposition is presented;

Proposition 1: B2B companies implement CSR activities closely related to their core business focus given that their visibility and engagement with customers are relatively low.

Secondly, results revealed that companies that engage in $\mathrm{B} 2 \mathrm{C}$ activities (selling products and/or providing services to individuals) tend to focus on external CSR initiatives as a response to normative institutional pressures to show stakeholders their sensitivity about the community and the world around them.
For example, Vestel and Arçelik, both of which manufacture consumer electronics, implement CSR initiatives focused on education, public health and sports, culture and the arts, and the environment. These activities tend to be discretionary and do not have any direct link with their core business focus. B2C companies have higher levels of socially responsible behavior as they are subject to more consumer pressure and media scrutiny due to their higher visibility (Bowen 2000; Hall 2000). Therefore, B2C companies are subject to greater pressure to construct a moral identity through implementing discretionary CSR initiatives.

Proposition 2: B2C companies implement CSR activities that are discretionary with a focus on ethical and philanthropic initiatives, given that their visibility and engagement with customers and the media are relatively high.

Thirdly, companies that work in both B2B and B2C (e.g. Coca-Cola Turkey, beer manufacturing company Anadolu Efes, Turkish Airlines) have an equal distribution of core business focused and discretionary CSR activities. They engage in CSR initiatives that are both closely linked to their core business focus as well as CSR initiatives that have a discretionary focus. This finding supports the conceptualization of CSR as a continuum in terms of basic responsibilities and restrictions which shape the nature of CSR activity as either core business focused or ethical and discretionary. Therefore, while CSR activities of B2B companies diffuse through coercive isomorphism due to economic and legal pressures and are related to their core business focus, CSR of B2C companies diffuse through normative isomorphism as they need to address the ethical and discretionary concerns of their stakeholders. Finally, when there is high uncertainty in the legal, socio-economic and political environment, CSR activities may diffuse through mimetic isomorphism, as companies will try to mimic popular practices to protect themselves and gain stakeholder support in an uncertain institutional environment.

The third research question aimed to reveal if there are any differences between the CSR initiatives of local versus multinational corporations. As argued by Jamali (2010), institutional theory can be utilized to understand the CSR initiatives of MNCs at the local 


\section{Business Ethics: A European Review}

Volume 25 Number 3 July 2016

level. Although MNCs implement global CSR activities that are in line with global standards or hyper norms (Husted \& Allen 2006), the current study's results revealed that they may remain weak at the local level due to not being implemented nationally.

While most of the investigated MNCs engage in several CSR initiatives and communicate these to global audiences via their international websites, they do not emphasize CSR at the local level. Two of the investigated MNCs (JIT and Sabanc1-Phillip Morris) did not emphasize CSR on their Turkish websites. This finding indicates that MNCs do not try to adapt to the local institutional environment or engage in locally-focused CSR initiatives, but implement CSR initiatives at the global level due to a lack of institutional pressures in developing countries (Özen \& Küskü 2009), and concern with global, not local, visibility. On the other hand, local companies implement CSR initiatives that address local community needs and standards.

Proposition 3: Multinational corporations do not heavily emphasize CSR initiatives at the local level in developing countries given that their focus is on addressing stakeholder concerns in the home country or at the global level.

As the total number of MNCs in Turkey's top 30 list were limited, inferences in regards to isomorphism mechanisms could not be further developed. However, future studies with a larger sample may reveal isomorphism mechanisms that shape the diffusion of MNCs' CSR practices in developing countries. The present study contributes to the literature by identifying whether there is a link between the type of CSR activity, industry, and organization type among Turkey's 30 largest companies.

\section{Conclusions}

This article studies the corporate social disclosures of the 30 largest corporations in Turkey through an institutional theory framework, and explains their CSR disclosure patterns according to industry and business type. Ma et al. (2012) highlighted the increased need for international studies in business ethics in the age of globalization. Thus, this study focused on Turkey as a developing country and stud- ied the influence of isomorphism mechanisms on CSR initiatives in this highly uncertain legal, socioeconomic, and political institutional environment. Turkey's largest 30 companies are influenced by institutional pressures (Can 2013), act in an isomorphic manner and mimic common CSR practices to fit the institutional environment. This study proposes that these isomorphic mechanisms are less industry based, but based more on organization type such as MNC versus local companies or B2B versus B2C businesses.

An important implication of this study is in regards to $\mathrm{B} 2 \mathrm{~B}$ and $\mathrm{B} 2 \mathrm{C}$ business type distinction and their CSR agendas. While B2B companies have a strategic CSR focus with economic and legal concerns investing in causes closer to their core business functions, B2C companies focus on philanthropic CSR initiatives that are more discretionary to impress stakeholders. As B2B companies have less visibility and fewer relationships, they may engage in CSR initiatives that tend to be more strategic and related to economic and legal responsibilities as well as industry standards to construct a moral identity. Conversely, as local companies operating in B2C markets have higher visibility and more direct relationships with their stakeholders, they need to engage in CSR initiatives with a stronger ethical and philanthropic focus. CSR activities of B2B companies diffuse through coercive isomorphism due to economic and legal pressures, but B2C companies need to address ethical and discretionary concerns and adopt CSR initiatives through normative isomorphism. Lastly, high uncertainty in the institutional environment causes CSR activities to diffuse through mimetic isomorphism where companies mimic common CSR practices to increase stakeholder support.

This finding is an important contribution to the literature as it highlights the significance of the national context and the local business environment in influencing CSR agendas. Results reveal that the focus of CSR is related to the nature of the business (B2B or B2C) in Turkish companies.

Furthermore, findings indicate that Turkey's 30 largest companies utilize CSR initiatives to construct a moral identity and global CSR trends influence the CSR agendas of these companies instead of immediate local needs. The cause behind this may be 


\section{Business Ethics: A European Review}

Volume 25 Number 3 July 2016

the relatively less-developed industry norms and loose regulations, which create more uncertainty, causing companies to mimic widely accepted CSR practices.

In addition, another important finding of this study is in regards to the CSR engagement strategy of multinational corporations. MNCs have limited CSR engagement in developing countries and they seem to be primarily oriented toward their home country or global-level CSR initiatives rather than focusing on host country needs. This may be explained with developing countries having relatively loose and fewer regulations and MNCs focusing more on their global reputation rather than reputation at the local level. The unique contribution of this study is to integrate CSR types with isomorphism mechanisms. Results reveal that while B2B companies focus on CSR activities linked to their core business functions, B2C companies focus on CSR initiatives that are more discretionary, varied, and philanthropic. In addition, findings show that MNCs implement CSR initiatives at the global level and industry characteristics do not directly influence the selection of the CSR initiatives.

\section{Study limitations and implications for future} research

This study investigated the 30 largest companies in Turkey and focused only on the industries these companies operate in. The authors acknowledge that studying 30 companies might be a limitation due to small sample size, but the exploratory nature of the study allowed researchers to develop some propositions to be addressed in the future. Future studies could examine a larger sample and expand to other industries to determine whether industry-specific CSR foci can be identified. In addition, the research only used secondary data and information available on corporate websites as companies in Turkey are not willing to participate in research projects, especially surveys. However, future studies could make use of primary data by including surveys or focus groups to understand the rationale behind companies' adoption of CSR initiatives. In addition, an external stakeholder survey could enable an assessment of external stakeholders' perceptions about corporations' CSR efforts, while a cross-cultural comparative analysis could be used to compare the CSR scene in Turkey with other developing countries.

\section{Appendix : CSR activity categories and focus according to business function}

\begin{tabular}{|c|c|c|c|c|c|}
\hline No & Company name/Industry & CSR activity categories & $\begin{array}{l}\text { Core business } \\
\text { focused CSR } \\
\text { initiatives }\end{array}$ & $\begin{array}{l}\text { Discretionary } \\
\text { CSR initiatives }\end{array}$ & $\begin{array}{l}\text { Total number } \\
\text { of CSR } \\
\text { activity } \\
\text { categories }\end{array}$ \\
\hline \multirow[t]{6}{*}{1} & Tüpraş/Manufacturing, Energy & Culture and arts & & $\checkmark$ & 6 \\
\hline & & Education & & $\checkmark$ & \\
\hline & & Environment & $\checkmark$ & & \\
\hline & & Occupational health and safety & & $\checkmark$ & \\
\hline & & Professional development & $\checkmark$ & & \\
\hline & & Public health and sports & $\checkmark$ & & \\
\hline \multirow[t]{5}{*}{2} & Petrol Ofisi/Retail Fuel Sales & Culture and arts & & $\checkmark$ & 5 \\
\hline & & Education & & $\checkmark$ & \\
\hline & & Environment & $\checkmark$ & & \\
\hline & & Occupational health and safety & $\checkmark$ & & \\
\hline & & Professional development & $\checkmark$ & & \\
\hline \multirow[t]{2}{*}{3} & Turkish Airlines/Air Transport & Environment & $\checkmark$ & & 2 \\
\hline & & Public health and sports & & $\checkmark$ & \\
\hline \multirow[t]{3}{*}{4} & Opet/Retail Fuel Sales & Culture and arts & & $\checkmark$ & 3 \\
\hline & & Education & $\checkmark$ & & \\
\hline & & Environment & $\checkmark$ & & \\
\hline
\end{tabular}

(Continued) 


\section{No Company name/Industry \\ 6 Phillip Morris-Sabancl/Tobacco \\ 7 Shell - Tucas Petrol/Retail \\ Fuel Sales}

CSR activity categories

5 Türk Telekom/Telecommunication Culture and arts

Disadvantaged groups

Education

Environment

Public health and sports

Social sensitivity

8 Arçelik/Domestic Appliences

9 Turkcell/Telecommunication

10 Enka Construction/Construction

11 BIM/Retail Trade, Grocery

12 Ford Otosan/Manufacture of Motor Vehicles

13 Erdemir/Manufacture of Basic Metals

14 Oyak-Renault/Manufacture of Motor Vehicles

15 Vestel Electronic/Manufacture of Consumer Electronics

16 TOFAS/Manufacture of Motor Vehicles

17 Hedef Alliance Group/ Warehousing and Storage
Public Health and Sports

Culture and arts

Education

Environment

Occupational health and safety

Culture and arts

Education

Environment

Public health and sports

Culture and arts

Disadvantaged groups

Education

Environment

Professional development

Public health and sports

Culture and arts

Education

Public health and sports

Education

Professional development

Public health and sports

Culture and the arts

Education

Environment

Occupational health and safety

Professional development

Culture and the arts

Environment

Professional development

Education

Public health and sports

Culture and the arts

Education

Environment

Public health and sports

Culture and the arts

Education

Public health and sports
Public health and sports
Total number of CSR

Core business focused CSR Discretionary activity initiatives CSR initiatives categories

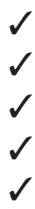

6

$\checkmark$

$\checkmark$

$\checkmark$

2

1

4

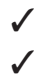

4

6

3

4

7

2

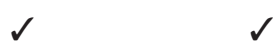

3

2

6

3

(Continued) 


\section{Appendix (Continued)}

\section{No Company name/Industry}

18 Migros/Retail Trade, Grocery

19 Anadolu Efes Biracılık/ Manufacture of Beverages

20 ICDAS Celik Enerji/

Manufacture of Basic Metals

$21 \mathrm{JTI}$ Tobacco/Tobacco

22 AYGAZ/Manufacture of Gas

23 Vodafone/Telecommunication

24 Sisecam/Manufacture of Glass

25 Mercedes-Benz Turk/ Wholesale and Retail of Motor Vehicles

26 Dogus Automotive/ Wholesale and Retail of Motor Vehicles

27 Selcuk Pharmacy Warehouse/ Warehousing and Storage

\section{CSR activity categories}

Culture and the arts

Disadvantaged groups

Education

Environment

Public health and sports

Culture and the arts

Environment

Professional development

Public health and sports

Culture and the arts

Education

Professional development

Public health and sports

Culture and the arts

Education

Environment

Occupational health and safety

Professional development

Public Health and Sports

Social sensitivity

Disadvantaged groups

Education

Environment

Occupational Health and Safety

Professional development

Public health and sports

Social Sensitivity

Culture and the arts

Disadvantaged groups

\section{Education}

Environment

Professional Development

Public health and sports

Disadvantaged groups

Education

Professional development

Culture and the arts

Disadvantaged groups

Education

Environment

Professional development

Public health and sports

Culture and the arts

Education

Public health and sports
Total number of CSR

Core business focused CSR Discretionary activity initiatives CSR initiatives categories 


\begin{tabular}{|c|c|c|c|c|c|}
\hline No & Company name/Industry & CSR activity categories & $\begin{array}{l}\text { Core business } \\
\text { focused CSR } \\
\text { initiatives }\end{array}$ & $\begin{array}{l}\text { Discretionary } \\
\text { CSR initiatives }\end{array}$ & $\begin{array}{l}\text { Total number } \\
\text { of CSR } \\
\text { activity } \\
\text { categories }\end{array}$ \\
\hline \multirow[t]{2}{*}{28} & Enerji SA/Electricity Supply & Environment & $\checkmark$ & & 2 \\
\hline & & Occupational health and safety & $\checkmark$ & & \\
\hline \multirow[t]{3}{*}{29} & Petkim/Manufacture of & Education & $\checkmark$ & $\checkmark$ & 5 \\
\hline & Chemicals & Environment & $\checkmark$ & $\checkmark$ & \\
\hline & & Public health and sports & & $\checkmark$ & \\
\hline \multirow[t]{8}{*}{30} & Coca-Cola/Manufacture & Culture and the arts & & $\checkmark$ & 11 \\
\hline & of Beverages & Disadvantaged groups & & $\checkmark$ & \\
\hline & & Education & & $\checkmark$ & \\
\hline & & Environment & $\checkmark$ & $\checkmark$ & \\
\hline & & Occupational health and safety & & & \\
\hline & & Professional development & $\checkmark$ & & \\
\hline & & Public health and sports & $\checkmark$ & $\checkmark$ & \\
\hline & & Social sensitivity & $\checkmark$ & $\checkmark$ & \\
\hline
\end{tabular}

Source: Authors.

\section{References}

Aggerholm, H.K. and Trapp, N.L. 2014. 'Three tiers of CSR: an instructive means of understanding and guiding contemporary company approaches to CSR?'. Business Ethics: A European Review, 23:3, 235-247.

Albert, S. and Whetten D. 1985. 'Organizational identity'. In Cummings, L.L. and Staw, B.M. (Eds.), Research in Organizational Behavior, Vol. 7: Greenwich, CT: JAI Press.

Amaeshi, K., Adi, B., Ogbechie, C. and Amao, O. 2006. 'CSR in Nigeria: Western mimicry or indigenous influences?'. The Journal of Corporate Citizenship, 24, 83-99.

Andersen, P.H. and Kumar, R. 2006. 'Emotions, trust and relationship development in business relationships: a conceptual model for buyer-seller dyads'. Industrial Marketing Management, 35:4, 522-535.

Arnott, D.C. 2007. 'Trust - Current thinking and future research'. European Journal of Marketing, 41: 9/10, 981-987.

Atakan-Duman. 2010. 'İs Sistemine Baglı Yapisal Farklilasma: Koc Holding ve General Motors Örnegi'. PhD dissertation. Ankara: Baskent University.

Aust, P.J. 2004. 'Communicated values as indicators of organizational identity: a method for organizational assessment and its application in a case study'. Communication Studies, 55:4, 515-534.

Berkman, Ü. and Özen, Ş. 2008. 'Culture and management in Turkey: state-dependency and paternalism in transition'. In Davel, E., Dupuis, J.-P. and Chanlat, J.-F. (Eds.), Gestion en contexte interculturel: approches, problématiques, pratiques et plongées: 129. Québec: Presse de l'Université Laval et Téléuniversité (UQAM).

Bhattacharya, C.B. and Sen, S. 2003. 'Consumer-company identification: a framework for understanding consumers' relationships with companies'. Journal of Marketing, 67:2, 76-88.

Bıçakçı, A.B. and Hürmeriç, P. 2013. 'Milestones in Turkish public relations history. Public Relations Review, 39, 91-100.

Bonsón, E. and Ratkai, M. 2013. 'A set of metrics to assess stakeholder engagement and social legitimacy on a corporate Facebook page'. Online Information Review, 37:5, 787-803.

Bonsón, E., Escobar, T. and Flores, F. 2008. 'Navigation quality as a key value for the webpage of a financial entity'. Online Information Review, 32:5, 623-634.

Bowen, F.E. 2000. 'Environmental visibility: a trigger of green organizational response?'. Business Strategy and the Environment, 9:2, 92-107. 


\section{Business Ethics: A European Review}

Volume 25 Number 3 July 2016

Buğra, A. 2005. 'Devlet ve iş adamları'. İstanbul: İletişim Yayınları.

Burton, B., Farh, J.L. and Hegarty, W. 2000. 'A crosscultural comparison of corporate social responsibility orientation: Hong Kong vs. United States students'. Teaching Business Ethics, 4:2, 151-167.

Campbell, J.L. 2007. 'Why would corporations behave in socially responsible ways? An institutional theory of corporate social responsibility'. Academy of Management Review, 32:3, 946-967.

Can, O. 2013. 'Predictors of hybrid organizational identity: evidence from the Turkish theatre field, 1923-1999'. PhD dissertation. İstanbul: Sabanc1 University.

Carroll, A.B. 1979. 'A three-dimensional conceptual model of corporate performance'. Academy of Management Review, 4:4, 497-505.

Carroll, A.B. 2010. 'Corporate social responsibility'. In Visser, W., Matten, D., Pohl, M. and Tolhurst, N. (Eds.), The A-Z of Corporate Social Responsibility: 106-113. Chichester: Wiley.

Castelló, I. and Lozano, J.M. 2011. 'Searching for new forms of legitimacy through corporate responsibility rhetoric'. Journal of Business Ethics, 100:1, 11-29.

Chapple, W. and Moon, J. 2005. 'Corporate social responsibility (CSR) in Asia: a seven country study of CSR website reporting'. Business and Society, 44: 4, 415-441.

Dacin, M.T. 1997. 'Isomorphism in context: the power and prescription of institutional norms'. Academy of Management Journal, 40:1, 46-81.

David, P., Kline, S. and Dai, Y. 2005. 'Corporate social responsibility practices, corporate identity, and purchase intention: a dual-process model'. Journal of Public Relations Research, 17:3, 291-313.

DiMaggio, P.J. and Powell, W.W. 1983. 'The iron cage revisited: institutional isomorphism and collective rationality in organizational fields'. American Sociological Review, 48:2, 147-160.

Du, S. and Vieira Jr., E.T. 2012. 'Striving for legitimacy through corporate social responsibility: insights from oil companies'. Journal of Business Ethics, 110: 4, 413-427.

Du, S., Bhattacharya, C.B. and Sen, S. 2010. 'Maximizing business returns to corporate social responsibility (CSR): the role of CSR communication'. International Journal of Management Reviews, 12:1, 8-19.

Erçek, M. 2006. 'HRMization in Turkey: expanding the rhetoric-reality debate in space and time'. International Journal of Human Resource Management, 17:4, 648-672.
Ertuna, B. and Tükel, A. 2010. 'Traditional versus international influences: CSR disclosures in Turkey'. European Journal of International Management, 4:3, 273-289.

Ertuna, Ö. and Ertuna, B. 2010. 'How globalization is affecting corporate social responsibility: dynamics of the interaction between corporate social responsibility and globalization'. In Aras, G. and Crowther, D. (Eds.), A Handbook of Corporate Governance and Social Responsibility: 323-340. Farnham: Gower.

Ettredge, M., Richardson, V. and Scholz, S. 2001. 'The presentation of financial information at corporate web sites'. International Journal of Accounting Information Systems, 2:3, 14-68.

Frynas, J.G. 2005. 'The false development promise of CSR: evidence from multinational oil companies'. International Affairs, 81:3, 581-598.

Gallego-Alvarez, I., Rodriguez-Dominguez, L. and Garcia-Sanchez, I. 2011. 'Information disclosed online by Spanish universities: content and explanatory factors'. Online Information Review, 35:3, 360-385.

Gökşen, N.S. and Üsdiken, B. 2001. 'Uniformity and diversity in Turkish business groups: effects of scale and time of founding'. British Journal of Management, $12: 4,325-340$.

González Benito, J. and González Benito, Ó. 2006. ‘A review of determinant factors of environmental proactivity'. Business Strategy and the Environment, 15:2, 87-102.

Greenwood, R., Suddaby, R. and Hinings, C.R. 2002. 'Theorizing change: the role of professional associations in the transformation of institutionalized fields'. Academy of Management Journal, 45:1, 5880.

Gummesson, E. 2008. 'Quality, service-dominant logic and many-to-many marketing'. The TQM Journal, 20:2,143-153.

Hall, J. 2000. 'Environmental supply chain dynamics'. Journal of Cleaner Production, 8:6, 455-471.

Hoejmose, S., Brammer, S. and Millington, A. 2012. "Green" supply chain management: the role of trust and top management in B2B and B2C markets'. Industrial Marketing Management, 41:4, 609-620.

Hsu, K.T. 2012. 'The advertising effects of corporate social responsibility on corporate reputation and brand equity: evidence from the life insurance industry in Taiwan'. Journal of Business Ethics, 109:2, 189-201.

Husted, B. and Allen, D. 2006. 'Corporate social responsibility in the multinational enterprise: strategic and institutional approaches'. Journal of International Business Studies, 37:6, 838-849. 


\section{Business Ethics: A European Review \\ Volume 25 Number 3 July 2016}

Jamali, D. 2010. 'The CSR of MNC subsidiaries in developing countries: global, local, substantive or diluted. Journal of Business Ethics, 93:2, 181-200.

Jamali, D. and Neville, B. 2011. 'Convergence vs. divergence in CSR in developing countries: an embedded multi-layered institutional lens'. Journal of Business Ethics, 102:4, 599-621.

Jamali, D., Zanhour, M. and Keshishian T. 2009. 'Peculiar strengths and relational attributes of SMEs in the context of CSR'. Journal of Business Ethics, 87:3, 355-367.

Jamali, D., El Dirani, A.M. and Harwood, I.A. 2015. 'Exploring human resource management roles in corporate social responsibility: the CSR-HRM cocreation model.' Business Ethics: A European Review, 24:2, 125-143.

Kolis, K. and Jirinova, K. 2013. 'Differences between B2B and B2C customer relationship management: findings from the Czech Republic'. European Scientific Journal, 4, 22-27.

Kotler, P. and Lee, N. 2005. Corporate Social Responsibility: Doing the Most Good for your Company and your Cause. Hoboken, NJ: Wiley.

Kurokawa, G. and Macer, D. 2008. 'Asian CSR profiles and national indicators: investigation through webcontent analysis'. International Journal of Business and Society, 9:2, 1-8.

Küskü, F. and Zarkada-Fraser, A. 2004. 'An empirical investigation of corporate citizenship in Australia and Turkey'. British Journal of Management, 15:1, $57-72$.

Lamberti, L. and Noci, G. 2012. 'The relationship between CSR and corporate strategy in mediumsized companies: evidence from Italy'. Business Ethics: A European Review, 21:4, 402-416.

Lee, M.Y., Fairhurst, A. and Wesley, S. 2009. 'Corporate social responsibility: a review of the top $100 \mathrm{US}$ retailers'. Corporation Reputation Review, 12:2, $140-158$.

Lichtenstein, D.R., Drumwright, M.E. and Braig, B.M. 2004. 'The effect of corporate social responsibility on customer donations to corporate-supported nonprofits'. Journal of Marketing, 68:4, 16-32.

Lindgreen, A., Swaen, V. and Johnston, W.J. 2009. 'Corporate social responsibility: an empirical investigation of U.S. organizations'. Journal of Business Ethics, 85:2, 303-323.

Long, B.S. and Driscoll, C. 2008. 'Codes of ethics and the pursuit of organizational legitimacy: theoretical and empirical contributions'. Journal of Business Ethics, 77:2, 173-189.
Luo, X. and Bhattacharya, C.B. 2006. 'Corporate social responsibility, customer satisfaction, and market value'. Journal of Marketing, 70:4, 1-18.

Ma, Z., Liang, D., Yu, K.H. and Lee, Y. 2012. 'Most cited business ethics publications: mapping the intellectual structure of business ethics studies in 2001-2008'. Business Ethics: A European Review, 21: 3, 286-297.

Maignan, I. and Ralston, D.A. 2002. 'Corporate social responsibility in Europe and the US: insights from businesses' self-presentations'. Journal of International Business Studies, 33:3, 497-514.

Maon, F., Lindgreen, A. and Swaen, V. 2010. 'Organizational stages and cultural phases: a critical review and a consolidative model of corporate social responsibility development'. International Journal of Management Reviews, 12:1, 20-38.

Marsden, C. 2000. 'The new corporate citizenship of big business: part of the solution to sustainability?'. Business and Society Review, 105:1, 9-25.

Matten, D. and Moon, J. 2008. 'Implicit and explicit CSR: a conceptual framework for a comparative understanding of corporate social responsibility'. The Academy of Management Review, 33:2, 404- 424.

McWilliams, A. and Siegel, D. 2001. 'Corporate social responsibility: a theory of the firm perspective'. Academy of Management Review, 26:1, 117-127.

McWilliams, A., Siegel, D.S. and Wright, P.M. 2006. 'Corporate social responsibility: strategic implications'. Journal of Management Studies, 43:1, 1-18.

Moreno, A. and Capriotti, P. 2009. 'Communicating CSR, citizenship and sustainability on the web'. Journal of Communication Management, 13:2, 157-175.

Olins, W. 1989. Corporate Identity: Making Strategy Visible Through Design. London: Thames \& Hudson.

Ozdora-Aksak, E. and Atakan-Duman, Ş. 2014. 'Türkiye'de Telekomünikasyon Sektöründe İnternet Üzerinden Örgütsel Kimlik İnşasında Kurumsal Sosyal Sorumluluğun Rolü’. Gazi Üniversitesi İletişim Kuram ve Araştırma Dergisi, 38, 132-147.

Ozdora-Aksak, E. and Atakan-Duman, S. 2015. 'The online presence of Turkish banks: communicating the softer side of corporate identity'. Public Relations Review, 41:1, 119-128.

Özen, Ş, and Küskü, F. 2009. 'Corporate environmental citizenship variation in developing countries: an institutional framework'. Journal of Business Ethics, 89:2, 297-313.

Özen, H. and Özen, S. 2004. 'Stakeholder influence on corporate social responsibility: implications of the 


\section{Business Ethics: A European Review \\ Volume 25 Number 3 July 2016}

Bergama case'. Symposium of the Changing Dynamics of the Corporation-Society Relationship: Integrative Approaches in the Academy of Management Annual Meeting, New Orleans, Louisiana.

Powell, W.W. and DiMaggio, P.J. 1981. The New Institutionalism in Organizational Analysis, Chicago, IL: University of Chicago Press.

Ravasi, D. and Schultz, M. 2006. 'Responding to organizational identity threats: exploring the role of organizational culture'. Academy of Management Journal, 49:3, 433-458.

Saini, A., Grewal, R. and Johnson, J.L. 2010. 'Putting market-facing technology to work: organizational drivers of CRM performance'. Marketing Letters, 21:4, 365-383.

Scott, W.R. 2008. Institutions and Organizations: Ideas and Interests. Thousand Oaks, CA: Sage.

Sethi, S.P. 1975. 'Dimensions of corporate social performance: an analytic framework'. California Management Review, 17:3, 58-64.

Sharma, S. 2000. 'Managerial interpretations and organizational context as predictors of corporate choice of environmental strategy'. Academy of Management Journal, 43:4, 681-697.

Sharma, A., Iyer, G.R., Mehrotra, A. and Krishnan, R. 2010. 'Sustainability and business-to-business marketing: a framework and implications'. Industrial Marketing Management, 39:2, 330-341.

Skouloudis, A. and Evangelinos, K. 2014. 'Exogenously driven CSR: insights from the consultants' perspective'. Business Ethics: A European Review, 23: $3,258-271$.

Story, J. and Neves, P. 2015. 'When corporate social responsibility (CSR) increases performance: exploring the role of intrinsic and extrinsic CSR attribution'. Business Ethics: A European Review, 24:2, 111-124.

Suchman, M.C. 1995. 'Managing legitimacy: strategic and institutional approaches'. Academy of Management Review, 20:3, 571-610.

Swanson, D.L. 1999. 'Towards an integrative theory of business and society: a research strategy for corporate social performance'. Academy of Management Review, 24:3, 506-521.

Türker, D. 2009. 'Measuring corporate social responsibility: a scale development study'. Journal of Business Ethics, 85:4, 411-427. van Riel, C.B.M. and Balmer, J.M.T. 1997. 'Corporate identity: the concept, its measurement and management'. European Journal of Marketing, 31:5/6, 340-355.

Verboven, H. 2011. 'Communicating CSR and business identity in the chemical industry through mission slogans'. Business Communication Quarterly, 74: 4, 415-431.

Visser, W. 2008. 'Corporate social responsibility in developing countries'. In Crane, A., McWilliams, A., Matten, D., Moon, J. and Siegel, D. (Eds.), The Oxford Handbook of Corporate Social Responsibility: 473-503. Oxford: Oxford University Press,

Wanderley, L., Lucian, R., Farache, F. and Sousa Filho, J. 2008. 'CSR information disclosure on the web: a context-based approach analyzing the influence of country of origin and industry sector'. Journal of Business Ethics, 82:2, 369-378.

Waters, R.D., Tindall, N.T.J. and Morton, T.S. 2010. 'Media catching and the journalist-public relations practitioner relationship: how social media are changing the practice of media relations'. Journal of Public Relations Research, 22:3, 241-264.

Wooten, M. and Hoffman, A. 2008. 'Organizational fields: past, present and future'. In Greenwood, R., Oliver, C., Suddaby, R. and Sahlin, K. (Eds.), The Sage Handbook for Organizational Institutionalism: 130-147. Thousand Oaks, CA: Sage Publications.

Zellweger, T., Nason, R., Nordqvist, M. and Brush, C. 2013. 'Why do family firms strive for nonfinancial goals? An organizational identity perspective'. Entrepreneurship Theory and Practice, 37:2, 229-248.

Zora, S. 2011. 'Customer evaluation of the corporate social responsibility practices: study on the Turkish banking industry'. Master's thesis. Istanbul: Boğaziçi University.

Emel Ozdora-Aksak, $\mathrm{PhD}$, teaches in the Department of Communication and Design at Bilkent University, Ankara, Turkey.

Sirin Atakan-Duman, $\mathrm{PhD}$, is an Associate Professor in the Department of Business Administration at Turgut Ozal University in Ankara, Turkey. 